\title{
Policy-Making of the Persian Gulf States Based on the Sustainable Development Goals in 2030 Agenda
}

\author{
Shima Naderi ${ }^{1}$ \\ ${ }^{1}$ Ph.D. Dept. of Environmental Law, Faculty of Natural Resources and Environment, Science and Research Branch \\ of Islamic Azad University of Tehran, Iran \\ Correspondence: Shima Naderi, Faculty of Natural Resources and Environment, Islamic Azad University, Science \\ \& Research Branch in Tehran, Iran. E-mail: shima.naderi_barrister@yahoo.com
}

Received: February 25, 2021

Accepted: April 8, $2021 \quad$ Online Published: April 15, 2021

doi:10.5539/jpl.v14n3p103

URL: https://doi.org/10.5539/jpl.v14n3p103

\begin{abstract}
The closure of the Persian Gulf environment and the passage of tankers and the overuse of this region beyond international standards, have endangered the environmental status of this gulf. The dissemination of maritime culture, water economy and the inclusion of its policies in the laws of the eight countries of the Persian Gulf is essential to achieve sustainable development, given its various dimensions and practices. The main question is how effective the performance of Persian Gulf states can be in sustainably developing the marine environment of the Persian Gulf with emphasis on economic, social and environmental indicators of sustainable development? This article has analyzed the performance of the Persian Gulf countries in relation to the sustainable development of the marine environment, in an analytical manner and as a library research and, thus, laws should be applied in the Persian Gulf region as a general obligation of governments to protect the marine environment, in the form of a system of regional cooperation. Consequently, it can be expressed that achieving sustainable development in the marine environment of the Persian Gulf, can only be made possible via all of the eight countries playing the optimal role in interaction with each other and the strict implementation of international agreements on marine pollution prevention. The application of the 17 SDGs and the indicators mentioned in the domestic laws of the regional countries, may provide opportunities for developed and developing countries to strengthen cooperation and partnership to attain ambitions and goals of sustainable development through protecting and using their resources properly. Ultimately, we will find out that the development of the indicators is influenced by the significant impact of the policies of influential governments.
\end{abstract}

Keywords: indicators of sustainable development, sustainable development goals, marine environment, Persian Gulf, 2030 agenda

\section{Introduction}

Sustainable development is the bedrock of all human activities that will have a great impact on the fate of all living things in the future. Since the issue of environmental protection has been raised globally as a common benefit for human beings, therefore, the common and public interests of humanity must be respected by present generations, as well as by humanity in the rights of future generations. Thus, degradation of environmental quality is a serious threat to human survival. Respecting human rights is directly and closely related to the protection and preservation of the environment. Also, participation in achieving human rights, such as health, education and legal services, the possibility of active participation in the labor market and participation in the public and political spheres, are other stages of achieving sustainable development (Stevens et.al, 2003). However, it is the core values of sustainable development that is still worth further considering and investigating. Economic development, caring about environment supporting standards and mechanisms, and ultimately following human well-being and their relevant social standards have always been among the prerequisites of realizing sustainable development goals. Therefore, sustainable development is like a triangle with three sides of paying simultaneous attention to the necessity of economy, human rights and environment. What clarifies the interconnection of these three pillars is considerable in various angles and it seems that lack of agreement on a unified interpretation from sustainable development, as well as having a multi-dimension attitude with a preferred aspect in mind, are the barriers of knowing this bond (Shahbazi, 2011).

In international environmental law, the purpose of holding governments accountable is not only to punish and 
penalize them, but also to compensate for environmental damage; hence, it seems unnecessary to prove the government's guilt and even it is considered a violation of intent. Governments are committed to SDGs. They are obliged to fulfilling their commitments with those goals in mind, and through the implementation of countless treaties which include the sustainable development goals, they push forward the true provisions of the goals (Barral, 2012). Reflecting on global environmental crises, countries are rapidly adapting to the sustainable development of 2030 Agenda, which has been merged with sustainable development goals and the Paris Agreement (Cabinet decision, 2018). The 2030 Agenda is the latest document for the sustainable development goals, which includes 17 general goals and 169 partial objectives. Then, this global guideline will be within the framework of the set goals, action models and activities of all countries in the upcoming 15 years after 2015. The realities of today's world show that no country can continue its natural and growing life without considering environmental issues and achieving sustainable development. The main purpose of this study is to explain the approach of the Persian Gulf states on sustainable development of the marine environment, with emphasis on indicators of sustainable development. Accordingly, the present article, while referring to the effects of sustainable development indicators on the marine environment of the Persian Gulf, seeks to answer the question that how policymaking of the countries of the Persian Gulf can be effective in the sustainable development of the marine environment of the region via emphasizing the economic, social and environmental indicators of sustainable development? For this reason, the concept of sustainable development should be considered in educational systems and individuals should be taught how individual rights and social responsibility in this field, contribute to the protection of the environment for future generations. Also, the protection of the marine environment, requires the development of a plan of corrective measures to reduce or eliminate the affecting pollutants, and the treatment of harmful and destructive effects on the marine environment must also be taken into account. It seems that due to the importance of this valuable water area and also to prevent any undesired event such as: pollution, war, etc., the neighboring governments, namely: Iran, Iraq, Saudi Arabia, Kuwait, Oman, UAE, Qatar and Bahrain, are expected to cooperate even far more than before. Governments follow established laws that have been passed internationally and domestically due to environmental issues and problems, and the spread of environmental pollutions. Thus, the importance of the issue is such that, based on more documents, an effective step can be taken in the development of the legal regime of the Persian Gulf, and international sustainable development law can be seen as a guarantor of its marine environmental protection. After examining the subject of the article, it can be clearly stated that research that has specifically investigated and analyzed the matter is far from the author's reach. In this paper, we examine the three indicators which are affecting sustainable development and related to the marine environment in each of the countries bordering the Persian Gulf, and by considering these indicators in these countries, we analyze their achievement level of sustainable development based on sustainable development goals in 2030 Agenda briefly.

\section{Investigating the Three Indicators of Sustainable Development Goals in the Persian Gulf Countries}

The Sustainable Development Goals set out in the "2030 Agenda" are more comprehensive than the "Millennium Development Goals" and appear to have been able to fill the past gaps significantly (Mitchell, 2013). They are also formal incentives for overall innovation in the pace of achieving sustainable development (Morton et al., 2017). Although this document is a global guideline, the four elements of "comprehensiveness", "transparency", "justice based approach" and "localism" have been neglected in formulating the goals of sustainable development (Pourhashemi, 2017:). Environmental law and policy must deal with many aspects of the physical world through scientific uncertainty. Additionally, environmental damage and degradation while increasing uncertainty, can often be measured after causal actions occur. In this situation, there are ambiguities about how to formulate environmental policies and allocate risk between present and future (Taqwadi, 2014). This region includes governments that are culturally different but have coordination and homogeneity in terms of strategic, economic and political issues. Six Arab Persian Gulf states aka.: UAE, Qatar, Kuwait, Oman, Saudi Arabia, and Bahrain formed a union called the Persian Gulf Cooperation Council in 1981 (IMF, 2005). Small or microstates of The Persian Gulf including: Qatar, Kuwait, Bahrain, the United Arab Emirates, and Oman, are geographically lacking in geopolitical area, depth, and scope. Each of these countries alone are unable to maintain political or security deterrence of their country; so they need the support of regional and supra-regional powers for their stability and security. ${ }^{1}$ In the southern part of the Persian Gulf, the three factors of territorial size, geopolitical depth and the quality of political systems are the main factors of political and security instability in the region. The combination of these three components has led the small Arab countries of the Persian Gulf region to act on the basis of defensive realism (Note 1). The establishment of political and security alliances with regional and supra-regional powers, and the presence of supra-regional powers in the region to provide political and security support to the

\footnotetext{
${ }^{1}$ Iran and Saudi Arabia are considered as regional powers of the eight states enclosed in this gulf. Britain left the Persian Gulf in 1971. The United States is trying to control other Persian Gulf states by establishing military bases.
} 
microstates of the southern Persian Gulf, confirm that the policy and guidelines of the Persian Gulf states is based on defensive realism in the region. This has lead political conflicts and supra-regional opposing security actions into the region (Khalili, 2008). The national security of the countries in the region is strongly tied to their economies, and their economies are linked to an important geopolitical factor called energy, oil and gas. These economic factors are monopolized by the governments of the region and the private sector is not allowed to participate and exploit this geopolitical factor (without the permission of their governments), and the competitive market in this region is in line with the competitive policies of governments to deepen their geopolitical influence. Reducing or increasing energy prices severely affects the plans of regional governments and challenges them in their development path. Internal instability created by lower energy prices has had negative effects, and because governments and rulers of the region's (Arab) political systems are derived from a particular social class, these price fluctuations are accompanied by fluctuations in national investment and it will directly affect the economic situation of the society and lead to social dissatisfaction in their communities (Hashemy and Faraji Rad, 2017). With all these interpretations, the attention of the great powers to the Persian Gulf region and the presence of two regional powers that increases competition in the region, is crucial in maintaining the security of the Persian Gulf region (Keshishian Siraki et. al., 2019).

The existence of different political systems at the national level, as well as different and sometimes conflicting views on national security, have led the countries in the region to seek to expand their regional influence and, accordingly, to expand their geopolitical territory in the region. This type of action plan has divided the region into two opposing factions, the first of which includes the front and supporters of the Islamic Republic of Iran (including Iraq, Syria and the Lebanese Hezbollah movement) and the second of which includes Saudi Arabia and its regional allies (including GCC countries along with Turkey and Jordan). Competition between regional governments for more power and centrality in the regional system is a matter that has led to usage of factors such as religion, ethnicity, or strategic tools like oil and strategic technologies e.g.: several-thousand-kilometer missiles, fighter jets, or nuclear technology (if possible atomic bomb), for being able to reach a position and power beyond other governments in the region. They take steps to achieve this goal that may result in the formation of different security systems in the region and it goes up to the point that they secretly sign informal treaties with Israel to achieve the superior regional position. (Hashemy and Faraji Rad, 2017). In this regard, it can be seen that sustainable development goals of the marine environment of the Persian Gulf, which is a set of social, economic and environmental indicators, are more or less influenced by political indicators and the probability of achieving the highest goal aka sustainable development goals, accompanies turmoil and crises.

\section{Investigating Components Affecting the Implementation of Sustainable Development Goals in Persian Gulf Countries}

Indicators of sustainable development are increasingly becoming popular tools for further monitoring progress and formulating effective policies to achieve sustainable development. The following table shows the combination of the three economic, social, and environmental indicators of sustainable development with including 15 main goals from the 2030 Agenda's 17 goals, and it also shows the direct impact of the indicators on the implementation of these goals, which was certainly not unrelated to the main goal number 16, namely world peace. From this perspective, developing countries in the Persian Gulf region should make more efforts to achieve this important and fundamental goal as a foundation for other goals; because with the flow of sustainable peace and management in the promotion of the rule of law, the goals of sustainable development in the direction of growth will be done properly. The experience of the Millennium Development Goals shows that development and progress have been hampered by the lack of a peace process and weak institutions in these areas. Thus, in the 2030 Agenda for Sustainable Development of United Nations, Goal 16 is considered a fundamental achievement for many other SDGs (SDG16+Progress Report 2019: Institute for Economics \& Peace, p.2.) 
Table 1. Main goals of sustainable development

\begin{tabular}{cl}
\hline & Goal 7. Ensure access to affordable, reliable, sustainable and modern energy for all, \\
Main goals of & Goal 8. Promote sustained, inclusive and sustainable economic growth, full and productive \\
Sustainable & employment and decent work for all, \\
Development, & Goal 9. Build resilient infrastructure, promote inclusive and sustainable industrialization and \\
Consisting of & foster innovation, \\
Economical Indicators & Goal 12. Ensure sustainable consumption and production patterns,
\end{tabular}

\begin{tabular}{|c|c|}
\hline & Goal 1. End poverty in all its forms everywhere, \\
\hline $\begin{array}{l}\text { Main goals of } \\
\text { Sustainable }\end{array}$ & $\begin{array}{l}\text { Goal 2. End hunger, achieve food security and improved nutrition and promote sustainable } \\
\text { agriculture, }\end{array}$ \\
\hline \multirow{7}{*}{$\begin{array}{l}\text { Development, Consisting } \\
\text { of Social Indicators }\end{array}$} & Goal 3. Ensure healthy lives and promote well-being for all at all ages, \\
\hline & Goal 4. Ensure inclusive and equitable quality education and promote lifelong learning \\
\hline & opportunities for all, \\
\hline & Goal 5. Achieve gender equality and empower all women and girls, \\
\hline & Goal 6. Ensure availability and sustainable management of water and sanitation for all, \\
\hline & Goal 10. Reduce inequality within and among countries, \\
\hline & Goal 11. Make cities and human settlements inclusive, safe, resilient and sustainable. \\
\hline Main goals of & Goal 13. Take urgent action to combat climate change and its impacts, Goal 14 . Conserve and \\
\hline Sustainable & sustainably use the oceans, seas and marine resources for sustainable development, \\
\hline Development, & Goal 15. Protect, restore and promote sustainable use of terrestrial ecosystems, sustainably \\
\hline Consisting of & manage forests, combat desertification, and halt and reverse land degradation and halt \\
\hline Environmental & biodiversity loss. \\
\hline \multicolumn{2}{|l|}{ Indicators } \\
\hline the Goal of Domestic & Goal 16. Promote peaceful and inclusive societies for sustainable development, provide access \\
\hline Security and World & to justice for all and build effective, accountable and inclusive institutions at all levels. \\
\hline \multicolumn{2}{|l|}{ Peace } \\
\hline the Goal of Creating & Goal 17. Strengthen the means of implementation and revitalize the global partnership for \\
\hline Cooperation and a New & sustainable development. \\
\hline International Order & \\
\hline
\end{tabular}

\subsection{Components Affecting the Implementation of Sustainable Development Goals in the UAE}

The UAE is one of the most developed countries in the Persian Gulf and is one of the richest countries in the world in terms of economics, which earns most of its income from oil revenues. The UAE has an authoritarian and undemocratic government. Despite the existence of social freedoms, economic progress and prosperity in the UAE, the country is at a low level in terms of participation and political freedoms, and civil institutions face many restrictions. (Bti, 2014). This country has long coastlines and benefits from the longest coastline in the Persian Gulf second to Iran. The UAE's coastal location, which is influenced due to its natural location in the Persian Gulf, has brought special benefits to the country. The vast oil resources of this country in the Persian Gulf region and its access to the Strait of Hormuz through its long coasts, have provided extensive facilities and revenues for the implementation of development projects and executing special plans for this country. On the other hand, the UAE, with enjoying its coastal location as well huge markets in the Persian Gulf region, is considered as the main port and distribution point of goods and services in the region thanks to developing and expanding of its ports (Alizadeh, 2015). The growth rate of the country's industrial production in 2009, It was 6.7 percent, which is ranked 118th in the world. In terms of GDP value, this country is next to Saudi Arabia among other countries. The Gulf Cooperation Council is the second largest country in the Middle East and North Africa, after Saudi Arabia and Iran rank third. It is also ranked fifth in terms of international trade freedom The world has. In 2006, the UAE raised $24.3 \%$ of its 
gross domestic product (Shirzadi, 2015). Human Development Index (HDI) Ranking, From the 2020 Human Development Report shows UAE is 31 in the world and Gross National Income is 67.462.

The UAE was among the first countries adopt 2030 Agenda for sustainable development in 2015 which encompassed the 17 Sustainable Development Goals (SDGs) ${ }^{2}$. The country contributed actively in moving from the Millennium Development Goals (MDGs) to the SDGs via adopting new sustainability framework within the global level and participating on high-level meetings on the new set of global goals and objects for the upcoming 15 years. Although the UAE seems committed to attain the 2030 Agenda goals both nationally and internationally, and shows to have multiple domestic and international policy instruments in place to ensure the country meets its obligations and ambitions by 2030 and beyond (UAE and the 2030 Agenda for Sustainable Development Excellence in Implementation, 2017), yet there is a long way ahead the state to comply completely with the SDGs standards in the Persian Gulf region.

\subsection{Components Affecting the Implementation of Sustainable Development Goals in Qatar}

Qatar as an oil and gas enriched country in the Persian Gulf region, is among the wealthiest countries in the world in terms of economics, which earns most of its income from gas revenues. The Emir of Qatar is the highest official and head of the Qatari government and is considered the highest decision-maker in Qatar. The Qatari constitution gives the Emir, full authority to issue decrees, as well as executive powers, and he has the three powers (aka executive, legislative, and judiciary sectors) (Qatar Green Book, 1997). On the bright side, the country enjoys a program aka the Qatar's National Vision which is aimed to make Qatar an advanced society which is capable of sustaining the development and providing a high standard of living for its people by 2030. The long-term goals for the country are defined in the program and it seeks to provide a framework in which, national strategies and implementation plans can be developed. The National Vision (Qatar GCO, 2015) deals with five challenges at the national level as follows:

- Modernization and preservation of traditions

- The needs of the current generation and of future generations

- Managed growth and uncontrolled expansion

- The size and quality of the expatriate labor force and the selected path of development

- Economic growth, social development, and environmental management

\subsection{Components Affecting the Implementation of Sustainable Development Goals in Iran}

Iran, considered as one of the oldest civilizations in the region and having the highest level of communication with the Persian Gulf countries, Iran has the most important role in sustainable development. Iran has used its full potential in bilateral trade with the UAE, and the share of Iran's unused non-oil trade capacity with the UAE has not been fully exploited. In this case, it sounds that the conclusion of a trade agreement between the two sides, will not affect the volume of trade between Iran and the UAE. Regarding unused non-oil trade capacity (e.g. carpet, fresh and dried fruits, tourism, etc.), Oman has the highest figure and the largest share of unused capacity of nonoil trade potential. In other words, Iran in its non-oil trade with Oman, has only been able to realize about $2 \%$ of its trade potential and still $98 \%$ of its non-oil trade potential remains unused. Following Oman, the largest share of unused capacity belongs to Qatar, Syria and Saudi Arabia, respectively. Thus, it can be said that Iran has not fully benefited its trade potential in non-oil trade with Oman, Syria and Qatar. Also, it has used only 70 to $80 \%$ of its potential in trade with Kuwait, Bahrain and Saudi Arabia, which could lead to the expansion of Iran's trade relations with these countries. The ground can be opened for the expansion of the market for potential products by strengthening the infrastructure, supporting domestic production and reducing tariff rates (Razini, Mirzainejad and

\footnotetext{
${ }^{2}$ Goal 1. End poverty in all its forms everywhere, Goal 2. End hunger, achieve food security and improved nutrition and promote sustainable agriculture, Goal 3. Ensure healthy lives and promote well-being for all at all ages, Goal 4. Ensure inclusive and equitable quality education and promote lifelong learning opportunities for all, Goal 5. Achieve gender equality and empower all women and girls, Goal 6. Ensure availability and sustainable management of water and sanitation for all, Goal 7. Ensure access to affordable, reliable, sustainable and modern energy for all, Goal 8. Promote sustained, inclusive and sustainable economic growth, full and productive employment and decent work for all, Goal 9. Build resilient infrastructure, promote inclusive and sustainable industrialization and foster innovation, Goal 10. Reduce inequality within and among countries, Goal 11. Make cities and human settlements inclusive, safe, resilient and sustainable, Goal 12. Ensure sustainable consumption and production patterns, Goal 13. Take urgent action to combat climate change and its impacts, Goal 14. Conserve and sustainably use the oceans, seas and marine resources for sustainable development, Goal 15. Protect, restore and promote sustainable use of terrestrial ecosystems, sustainably manage forests, combat desertification, and halt and reverse land degradation and halt biodiversity loss, Goal 16. Promote peaceful and inclusive societies for sustainable development, provide access to justice for all and build effective, accountable and inclusive institutions at all levels, Goal 17. Strengthen the means of implementation and revitalize the global partnership for sustainable development.
} 
Shirinzadeh, 2015).

The geo-economic characteristics of Iran and Oman justify any cooperation between the two countries. Characteristics such as a common water border, location in the adequate environment of the world economy, pristine access to each other and the special economic and security conditions of the Strait of Hormuz that necessitate cooperation between the two countries, are the most substantial factors that justify the economic and security relationship between the two states. Building a partnership based on these components can accelerate a clear and promising path for the development of relations with other neighboring countries.

\subsection{Components Affecting the Implementation of Sustainable Development Goals in Kuwait}

Kuwait is a small country with a lot of influence in the region which is neighbor of a powerful country called Iraq. Kuwait's policy in the Persian Gulf has always been to Iran's detriment and to Iraq's advantage due to its support for Arab nationalism and fear of Iraq. Of course, this policy has ended to the detriment of Kuwait as well. Iran has always supported Kuwait's territorial integrity and independence in the face of Iraq's expansionist ambitions, while Kuwait has sided with Iraq and the UAE in disputes between Iran and Iraq or Iran and the UAE (Jafari Valdani, 2009). This State adopted SDGs in September 2015 officially and decided to describe the Goals as goes: to include the SDGs within the first national development plan of Kuwait Vision 2035; comply with SDGs through the national institutional development framework, plans, budget and national governance structure; engage government entities, civil society, private sector and other stakeholders at the policy, and institutional levels together with allocating resources for advocacy and consensus building. The country integrated efforts officially to take SDGs as part of its national duties via the establishment of National Sustainable Development Committee (NSDC) and National Observatory on Sustainable Development (NOSD). Holding more than 13 national workshops by the General Secretariat of the Supreme Council for Planning and Development (GSSCPD) along with Central Statistical Bureau (CSB), they aimed at addressing sixty-six entities from government, nongovernment and private sector partners generally. By these workshops, the state tried to offer opportunities to discuss \& define priorities in SDGs in domestic level, interact with stakeholders about their roles to attain these goals, and express the goals of Kuwait National Development Plan (2015-2020). The Government also invested in national awareness of the 2030 Agenda scope. Kuwaitis claim that they tried to set strategic paths of overcoming challenges ahead of the state e.g. strengthening the role of private sector, reducing dominance of oil sector on the economy, balancing public budget, creating conditions for reinvigorated direct foreign investments and improving infrastructure, implementing strategic development projects for achieving relevant SDGs and their targets (HLPF Report, 2019). The Kuwait's 2019 Voluntary National Report (VNR) is developed with the same idea and the country's Leadership wishes to show their dedication to strategic, institutional framework and the government's role in the short, medium and long term for achieving SDGs mentioned within 2030 Agenda and Kuwait Vision 2035.

\subsection{Components Affecting the Implementation of Sustainable Development Goals in Saudi Arabia}

Saudi Arabia is one of the largest and most pivotal countries in the region, and is a very special country in the political sphere of the Middle East. The country acts with a guardant manner toward most of the Arab countries due to its high income resulting from oil export. (Pahlavani, Golestani, 2016). Saudi Arabia is one of the 10 countries out of the 49 countries in the world that have been introduced as "countries deprived of freedoms" which have the worst scores in the category of political rights and civil liberties (Repucci, 2020). Saudi Arabia has the most influence in the Organization of Islamic Cooperation, the Persian Gulf Cooperation Council and among the Arab countries, and this regional prestige can be an opportunity for them to advance the 2030 Agenda, which the officials of that country have certainly set it in mind. Apparently, the agenda is a thoughtful and intelligent program that its strengths and weaknesses has been measured as well as the future which is based on it, and it is certainly known where it is now and what position it will reach in the future. However, one of the weaknesses of this program may be the lack of political reforms; therefore, it can be said that there are traces of political goals behind these socio-economic reforms. ${ }^{3}$ Finally, it is highly unlikely that Saudi Arabia, with this aggressive and tense foreign policy and spending astronomical costs on the military dimension, will be able to fully implement the 2030 Agenda within the allotted time.

\footnotetext{
${ }^{3}$ Economic Reforms: Saudi Arabia begins accepting licence applications in the military industrial sector, a major target for diversifying the economy away from oil (2019).

Socio Reforms: A new tourist visa regime seeks to attract holidaymakers. A modest dress code is set for visitors, ending the requirement that women wear all-covering robes. Foreign men and women are permitted to rent hotel rooms together without proving they are related (Octobr 2019).
} 


\subsection{Components Affecting the Implementation of the Sustainable Development Goals in Bahrain}

Bahrain is another Arab country in the vicinity of Persian Gulf. United Nations Environment Program Regional Office for Arab States was launched in 2015 under the Youth Leadership Programme to create the most dynamic regional network for young people in order to innovate and find ways to achieve sustainable development. The program is designed to empower a generation of young leaders, social actors and innovators to grow their capacity in line with the goals of sustainable development in Bahrain and other Arab countries. The country tried to show its dedication to SDGs through the King's comprehensive development plan, and the launch of "Economic Vision 2030" - including the principles of sustainability, competitiveness and fairness - which is claimed to be aiming at doubling the Bahraini households' income by 2030.

The economic diversification, and sustainable and comprehensive development are the main government's concerns in this regard. They claim to be successful in terms of the Millennium Development Goals and setting the foundation for the SDGs (HLPF Report, 2018). The statistics that they offer in this regard are as follows:

- Percentage of the population living in extreme poverty is zero.

- Average economic growth in the past decade stands at 37.4\% and average GDP per capita is USD 22,000.

- Public expenditure on health, education, and social protection exceeds $35 \%$ of the budget.

- Basic education is free and compulsory.

- Healthcare is free and universal.

- The Constitution guarantees gender equality. There are two committees instituted by the Supreme Council for Women to ensure equal opportunities and gender-responsive budgeting. Women hold 55\% of the supervisory positions, with $53 \%$ and $33 \%$ participation in the public and private sector respectively.

- The private sector is a key development partner. It provides equal high paying employment opportunities contributing to lowering total unemployment to $4 \%$.

- $65 \%$ of the population benefited from public housing services with five new sustainable cities being developed.

- The coverage of safe water, sanitation and clean energy networks reached 100\%.

\subsection{Components Affecting the Implementation of Sustainable Development Goals in Iraq}

Iraq is another country in the region with the least coastline in the Persian Gulf. However, the country's war against Iran and Kuwait, had irreparable consequences for the region (Moeinabadi Bidgoli, Sadri Ali Babalu, 2014). Vast area of Iraq was under the control of ISIL since 2014 to the beginning of 2019, and there was a long and continuous conflict between the Iraqi armed forces and ISIL fighters. Certainly, it is useless to expect the implementation of key indicators sustainable development during the years after the emergence of ISIL in Iraq as an unprecedented global threat to international peace and security which committed sexual violence, rape, sexual slavery, recruitment of children in armed groups, use of civilians as human shields, etc. (Saedi, Arashpour, Farzami Nasab, 2019). Undoubtedly, repairing and rebuilding through the existing conditions requires strong authority from the new government. The government was fighting back its dominance over the homeland against ISIL terrorists while 2030 Agenda and its 17 Sustainable Development Goals (SDGs) were adopted by all Member States of the United Nations in September 2015. Furthermore, Iraqis always sought a better overall future during the current century the previous one. In this country, Ministry of Planning is the focal point for coordinating, monitoring and reporting on the implementation of the 2030 Agenda and the SDGs. National Committee for Sustainable Development is supposed to regulate the economic, social and environmental activities among national and local government actors together with the private sector, civil society and local and international organizations to ensure that all groups and regions of Iraq can participate in and benefit from development progress. They strive to promote awareness and ownership of the SDGs and its inclusiveness through national and subnational plans, while absorbing more support from development partners for implementing the aforementioned plans.

The progress of implementing the Iraq Vision 2030 priorities and other SDGs namely, human development (SDGs 1, SDG3, SDG4 and SDG5), good governance and safe society (SDG16), economic diversification (SDG8 and SDG9), sustainable environment (SDG6, SDG11 and SDG13) can be evaluated via the below results. The Iraq National Development Plan (NDP, 2018 - 2022) and Iraq Governmental Program, claim the inclusion of the abovementioned goals as much as possible. They report that the NDP aligns with more than $70 \%$ of the SDG targets. Government has taken steps towards the betterment of governance and the rule of law, including administrative decentralization, the establishment of a high anti-corruption council, and reforms of the financial management and service delivery systems. The state also claims to create an enabling environment for the private sectors via implementing mega-projects, which are said to be planned to transforming the Iraq's development path through 
lowering oil reliance. Several challenges are yet to be cleared to get to sustainable development. For instance, twothirds of the population are displaced by the crisis (ISIL) of which, close to 2 million people have not yet made their way back home. The reconstruction process is estimated to cost USD 88.2 billion as well. The country has yet to secure political stability, strengthen national dialogue and establish inclusive and accountable governance frameworks at federal and local levels. Iraq must clear the challenges of demographic pressures, water crisis and the effects of climate change. However, the challenges are opportunities for the administration to display their determination and expand partnerships to secure more points in achieving SDGs. (HLPF Report, 2019)

\subsection{Components Affecting the Implementation of Sustainable Development Goals in Oman}

Oman is another country in the Persian Gulf region that, due to its membership in the World Trade Organization, is an economically moderate country among the countries of the region, and like other countries of the Persian Gulf, is dependent on crude oil exports. Compared to other countries in the region, the cost of oil production in this country is substantially high due to its geological features. The UAE is also one of Oman's most important trading partners. Oman's gross domestic product in 2009 was about $\$ 62.55$ billion and the growth rate of this index in 2010 was about 2.4 percent. Average income The per capita population of Oman, due to the global increase in oil prices, has risen from $\$ 7481$ in 1998 , it reached $\$ 25,600$, in 2010. It is estimated that the inflation rate The country's economy in 2010 was about 2.3 percent (Hafeznia and Rabiee, 2013). The next decade will require Oman to be even more adept in its competitiveness as the region itself tries to find its new bearings. Take tourism for instance; Oman hopes to double its contribution to GDP from around 3 per cent today to 6 per cent by 2040 and the industry is expected to generate half a million jobs by then. Over the next 20 years, Oman will most likely be facing stiff competition in this area not only by the UAE but by Saudi Arabia as well (Chatham House, 2020). Contrary to the rest of the Persian Gulf states, Oman has limited oil and gas resources, and cannot provide as much rental services as its counterparts in the southern Persian Gulf (Mokhtari and Adami: 2017). The peace-seeking behavior of this country during the imposed war between Iran and Iraq, can be considered as a case of in social indicator. The government made its effort to integrate the SDGs into their national development plans via adjusting their development strategies and plans, and allocating budgets to ensure their achievement in the medium and long term periods. In Human Development Report 2019, Socioeconomic sustainability of Oman was calculated 31.3 between 2015-2018 and ranking in the world is 47, therefore in the age of climate change, renewable energy is a serious economic opportunity, which Oman has to keep pursuing. If cheap electricity is generated it could also be exported to other Gulf states and to south Asia. In Oman, the share of renewables in total electricity capacity was around 0.5 per cent in 2018; the ambition is to reach 10 per cent by 2025. The National Voluntary Report (Oman una, 2021) confirms the Sultanate of Oman's commitment to achieving SDGs in three realms of economic, social and environmental dimensions within the mentioned timeframe. Generally speaking, despite the challenges against in the path, the state appears to move in the right direction toward attaining the goals, via balancing international relations with its Arab, regional and international surroundings. This balance is reinforced by the country's broad community presence when designing, implementing and evaluating plans, policies and programs that meet the challenges and achieve the desired goals.

\section{Performance of the Persian Gulf Countries to Achieve the SDGs According to 2030 Agenda}

Arab countries of the Persian Gulf region are distinguished in characteristics and qualities while having a homogeneous political-cultural basis dominant within them. On one side there has always been a background conflict due to presence of religious and ethnic communities, several social tendencies, and specific cultural structure in the region, and it is worth reflecting how these domestic attitudes, political-cultural basis, and particularly, Arab countries of the Persian Gulf region, face the globalization in broader image (Sanaei, Eirajifar, 2013).

Recent developments in the economic, social, political and military environment of the Middle East region, have led to huge changes and evolutions in development indicators. The Middle East region, especially the Persian Gulf, has a special geo-economic role in the global arena due to encompassing more than $60 \%$ of energy production resources (oil and gas). The results of the study of sustainable development indicators showed that, the United Arab Emirates and Qatar are the efficient countries in the Middle East with an efficiency of one percent, and Iraq, Yemen and Syria are the inefficient countries in terms of sustainable development indicators with an efficiency of $0.974,0.961$, respectively. Additionally, more than $60 \%$ of Middle Eastern countries perform in average level in terms of relative efficiency in sustainable development indicators. Important factors that have prevented Middle Eastern countries from achieving excellent performance levels in terms of sustainable development indicators compared to other developed countries, are as follows:

- The first factor of underdevelopment, goes back to the political situation and oil-rich countries in this area. 
- The second factor is the major dependence of countries on oil revenues, which has led to rent-seeking behaviors, strengthening bureaucracy, and limiting and weakening democratic institutions.

- The third obstacle in the development process of these countries, is gender inequality and the lack of serious participation of women in the development process of these countries, which prevent the exploitation of the benefits of half of the population of these nations.

- Another feature of the region is the special colonial heritage in the area and the greed of world powers to dominate the vast hydrocarbon reserves of the region, which has practically led to the formation of some dependent states and thus, limited democracy and political pluralism consequently. Human indicators in Middle Eastern countries such as (Syria, Yemen, Iraq, etc.) has declined sharply as a result of the devastating war, because countries in this area have not yet been able to improve their human well-being and social welfare status. It goes without saying, that the welfare indicator in Iraq had a downward trend even before the advance and establishment of ISIL (Safar Alizadeh et al., 2018).

Since most of the Persian Gulf countries' income comes from the sale of oil resources, any oil boom will have an impact on the states' political economy of the region, and with the influx of oil revenues into the political economy of oil-exporting countries, the scope of authority of such governments increase as well. Therefore, the increase in oil revenues of Iran and Saudi Arabia in the first decade of the 21st century, should be considered among the factors that have made the necessary grounds for the spread of the crisis in the region inevitable (Carl, 2012). Iran and Saudi Arabia are also trying to take strategic intervention in regional areas, including the eastern Mediterranean, with various goals and motives. In accord to the Freedom House non-profit organization, different parts of the world have seen a significant decline in freedom during last decade, and Kuwait has been an averagely ranked country, while the UAE and Bahrain have been among the countries with less than normal freedom (Repucci, 2020). While the whole world is dealing with the terrible consequences of the pandemic conditions, it makes success in maintaining the 2030 Agenda goals for sustainable development even harder for most of Arab countries. Following the first report (2015), the second edition (2020) of the Arab Sustainable Development Report (ASDR (Note 2)) which is delivered by the United Nations, aka working in the Arab region led by the United Nations Economic and Social Commission for Western Asia (ESCWA, 2020), notifies about the region to not to achieve the SDGs up to 2030.

Nevertheless, the High Level Policy Forum on "Localization of Sustainable Development Goals" provides a comprehensive summary of the progress of regional and local governments around the world, as well as a variety of innovative actions and approaches to localization with the topic of "Transformation in Sustainable and Resilient Societies" on a yearly basis. In addition, it explains the sustainable development goals and provides a detailed and in-depth assessment of the "Sustainable Cities and Communities" initiatives. Iran has not participated in this forum out of the eight Persian Gulf states, and Qatar has taken part in it twice in 2017 and 2018.

\section{Conclusions}

With regard to the concept of sustainable development, natural, economic and cultural resources should be preserved for the future generations, while being efficient and beneficial for the present society. Hence, sustainable development is an instrument to manage for nowadays and to invest for future in order to protect it from unintentional damages while making use of it. Therefore, sustainable development is flexible and depends entirely on the conditions of the region regarding the culture, geography, national laws, and regional policies. The semienclosure and unique geopolitical conditions of the Persian Gulf, make this bay unique among other watersheds of the world. It appears that due to the importance of this valuable water area and the prevention of any unwanted events, including: pollution, war, etc., the cooperation of the bordering states, namely: Iran, UAE, Bahrain, Iraq, Saudi Arabia, Oman, Qatar, Kuwait is expected even more than before. For this reason, it is not fair to do nothing to protect it from being polluted. The current approach some of the Persian Gulf countries regarding protecting the region in terms of protective and even security arrangements, is so that their leaders believe that supra-regional powers should leave the Persian Gulf, and a collective security system should be established with the participation and cooperation of all Persian Gulf countries. This indicates a conflict of views in the Persian Gulf and the continuing persistence of negative competition and mistrust, which the supra-regional powers, given their interests and goals in the region, contribute to reduce mistrust and support the formation of local security arrangements. On this basis, the countries of the Persian Gulf must observe indicators and sub-criteria of sustainable development principles which are composed of important social, economic and environmental indicators, and make development economically useful and compatible in an environmentally sustainable, socially just and communitybefitting manner.

As the protection of the environment, guarantees the establishment of peace in the region (and vice versa), 
establishment of order at the regional level, as well as the genuine cooperation; via trust building massively, we can discover solutions to overcome the huge barrier of environmental problems and issues, and save the rich heritage of the region which relies on valuable resources. Hence, unique political and cultural currents and homogeneity are dominant among the Arab countries of the Persian Gulf. On the other hand, special politicalcultural structure, as well as presence of religious and ethnic communities and their attitudes, have always made this marine area, an arena for regional and international conflicts. The legitimacy of the power of political systems, leaders and governing bodies in all these countries, have been acquired traditionally and the power has been inherited as well.

As mentioned, the countries of the Persian Gulf region have not achieve a high level of performance in terms of sustainable development indicators, compared to other developed countries due to factors such as countries' dependence on oil revenues that have led to rent-seeking behaviors, strengthened bureaucracy and restrictions and weakened democratic institutions, and the political and oil-rich situation of these states, resulted in gender inequalities and lack of serious participation of women in the development process (which prevents benefitting from half of the population of these countries). Put it differently, it must be stated that the concept of sustainable development is used as a magic wand among governments to create sustainable economic development and prosperity in modern societies, provide environmental sustainability in traditional and indigenous societies, and the concept of sustainability originates in this social entanglement between local, national, regional and global levels. Ultimately, achieving sustainable development of the Persian Gulf states, is possible only by all eight countries to play their optimal role in cooperation with each other. Thus, it is necessary to prepare a joint document with the meetings of countries in order to have a correct orientation in the direction of applying the indicators of sustainable development in the Persian Gulf region, following the example of the Sustainable Development Goals in 2030 Agenda.

Iran has a higher position in the social index compared to the Arab countries in the Persian Gulf. It seems that over time, countries such as Kuwait, Saudi Arabia and Oman, have shown a desire for sustainable development and the goals of the 2030 Agenda related to the marine environment of the Persian Gulf in recent years due to their growing trend; Iraq and other countries of the region which are involved in war, have priorities of sustainable development education and development of environmental principles education in the region.

\section{References}

Alizadeh, M. (2015). Construction of an artificial island by the UAE United Arab from the perspective of international law. Legal Discourse Quarterly, 12(27\&28), 76-61.

Barral, V. (2012). Sustainable Development in International Law: Nature and Operation of an Evolutive Legal Norm. The European Journal of International Law, 23(2), 377-410.

BTI. (2014). Tunisia Country Report. Retrieved from http://www.bti-project.org

Carl, T. L, (2012). The riddle of abundance; Oil Booms and Oil Governments (Jafar Khairkhahan. Trans, 2nd ed.). Tehran, Ney Publishing.

Green Book of Qatar. (1997). Tehran, Office of Political and International Studies, Ministry of Foreign Affairs.

Hafeznia, M. R., \& Rabiee, H. (2013). Persian Gulf Regional Studies. Samt Publications. Tehran.

Hashemy, S. M., \& Faragyrad, A. (2017). Factors Influencing Political and Security Instability in the Persian Gulf. Quarterly journal of International Relations Research, 6(22), 267-293.

http://www.unep.org/ozone/pdfs/viennaconvention 2002. (30.10.2019)

https://omanportal.gov.om/wps/portal/index/sdg

https://sustainabledevelopment.un.org/memberstates/kuwait

https://www.chathamhouse.org/2020/01

https://www.gco.gov.qa/en/about-qatar/national-vision2030

https://www.unescwa.org/events/postponed-arab-forum-sustainable-development-2020

https://www.unescwa.org/news/arab-region-will-not-achieve-SDGs

Human Development Report 2019 Beyond income, beyond averages, beyond today: Inequalities in human development in the 21st century, Published for the United Nations Development Programme (UNDP).

International Monetary Fund. (2005). Regional Monetary Integration in the Member States of the Gulf Cooperation Council. Washington. 
Khalili, H. (2008). Favorable priorities of the security system in the Persian Gulf. Journal of Strategic Attitude, 99(9), 241-254.

Kishishian sirki, Gh., Soheili Najafabadi, S., Ghaedi, M. R., \& Simbar, R. (2019). The Survey of Military Policies Effects on Persian Gulf Regional Security. International studies journal, 16(1), 155-182.

Mitchell, T., Jones, L., \& Lovell, E. (Eds.). (2013). Disaster Management in Post-2015 Development Goals: Potential Targets and Indicators. London, UK: ODI. Retrieved from http://www.odi.org.uk/sites/odi.org.uk/files/odiassets/publications-opinion-files/8354.pdf

Moeinabadi Bidgoli, H., \& Sadriali Babalo, S. (2017). A Comparative Study of America's Diplomacy toward Iraq's War against Iran and Kuwait. Quarterly Journal of Political Research in Islamic World, 125-150.

Mokhtari, M., \& Adami, A. (2017). Economic Requirements for the Development of Oman-Iran Relations. International Relations Research Quaterly, 72(3), 207-232.

Morton, S., Pencheon, D., \& Squires, N. (2017). Sustainable Development Goals (SDGs), and their implementation A national global framework for health, development and equity needs a systems approach at every level. British Medical Bulletin, 124, 81-90.

Pahlavani, E., \& Golestani, M. (2016). Investigating the Impact of Globalization on the Political Culture of Women in the Persian Gulf Countries "Case study: Islamic Republic of Iran and Saudi Arabia". Persian Gulf Cultural and Political Studies Quarterly, (8), 87-137.

Pourhashemi, S. A. (2017). Overview of Capacities and Barriers to Achieving Sustainable Development Goals: From Agenda 21 to Agenda 2030. Quarterly Journal of Environmental Science and Technology, Islamic Azad University, Research Sciences Branch, Association of Environmental Specialists, 7-18.

Razini, E. A., Mirzaeinehad, M. R., \& Shirinzadeh, M. (2016). Survey of Trade Potentials between Iran and Potential Candidate Countries in Region (Turkey, Syria, Kuwait, Oman, Bahrain, Qatar, Saudi Arabia, United Arab Emirates). The Gravity Model Approach, Iranian Journal of Trade studies (IJTC), 20(77), 147-167.

Repucci, S. (2020). Freedom in the World 2020. Freedom House.

Saedi, B., Arashpour, A., \& Farzami Nasab, A. (2019). Iraq's armed conflict; "Analysis of ISIL's actions from the perspective of international humanitarian law and international criminal law. Quarterly Journal of Public Law Studies, 2(49), 809-836.

Safaralizadeh, E., Hosseinzadeh, R., \& Akbari, M. (2018). The Analysis of the Relative Performance of the Middle East in Terms of Sustainable Development Indices. Journal of Regional Planning, 1-12.

Sanaei, A., \& Eirajifar, T. (2013). The Impact of Globalization of Communications on the Political-Cultural Structure of Kuwait. Quarterly Journal of Political Studies, 20(5), 91-111.

SDG16+Progress Report 2019: Institute for Economics \& Peace.

Shahbazi, A. (2010). Sustainable Development or Sustainable Development in International Law. May Bobe. Journal of International Affairs, 42.

Shirzadi, R. (2015). The factors of Human Development in United Arab Emirates, Journal of Contemporary Political Studies, 6(16), 107-124.

Stevens, A., Bur, A. M., \& Young, L. (2003). people, yobs, Rights\& Power. The Rules of participation in combating social Exclusion in Europe. Community Development journal, 38(2).

Taliaferro, J. W. (2001). Security Seeking under Anarchy. International Security, 25(3), 158-159.

Taqwadi, D. A. (2014). International Environmental Law: Development, Principles and Mechanism. Lembaga Kajian Hukum Aceh/Aceh's Legal Studies, 1-16.

The Basic Environment Plan. (2018). Cabinet decision on April.

\section{Notes}

Note 1. The foreign policy of defensive realism is the opposite of the aggressive foreign policy, and governments express their desire to merely increase the relative security of governments in the international arena. As a result, governments try to enhance their level of security, and they will expand their influence and power on the occasion of feeling insecure." (Taliaferro, 2001).

Note 2. The foreign policy of defensive realism is the opposite of the aggressive foreign policy, and governments 
express their desire to merely increase the relative security of governments in the international arena. As a result, governments try to enhance their level of security, and they will expand their influence and power on the occasion of feeling insecure." (Taliaferro, 2001).

\section{Copyrights}

Copyright for this article is retained by the author(s), with first publication rights granted to the journal.

This is an open-access article distributed under the terms and conditions of the Creative Commons Attribution license (http://creativecommons.org/licenses/by/4.0/). 